DOI https://doi.org/10.30525/978-9934-588-81-5-1.44

\title{
НАПІВЖОРСТКІ РОЗВАНТАЖУВАЛЬНІ СИСТЕМ ФІКСАЦІЇ У ХВОРИХ З ЗАХВОРЮВАННЯМИ ЧИ ТРАВМАМИ КІНЦІВОК
}

\author{
Рушай А. К. \\ доктор медичних наук, \\ професор кафедри загальної хірургії № 2 \\ Киїський медичний університет \\ Лісайчук Ю. С. \\ доктор медичних наук, \\ професор кафедри загальної хірургї̈ № 1 \\ Київький медичний університет \\ Жагдаль А. А. \\ аспірант кафедри загальної хірургії № 2 \\ Київський медичний університет \\ Мартинчук О. О. \\ аспірант кафедри загальної хірургії № 2 \\ Київький медичний університет \\ Байда М. В. \\ аспірант кафедри загальної хірургії № 2 \\ Київський медичний університет \\ м. Київ, Україна
}

Актуальність проблеми. Створення оптимальних умов при лікуванні травм та захворювань кінцівок $є$ до кінця не вирішеною проблемою. Комплексна терапія патології включала як проведення адекватної консервативної терапії, ранньої реабілітації, так і раціональну фіксацію ураженого сегменту. Об'єктивізація показників для вирішення об'єму консервативної терапії, строків сучасної фіксації потребує подальшого вивчення $[1,2]$.

Мета роботи. Поліпшення результатів лікування хворих на діабетичну остеоартропатію та травмами 3 використання напівжорсткої системи фіксації Scotchcast / Softcast і обгрунтованої комплексної терапії з максимально ранніми реабілітаційними заходами.

Матеріали і методи. Під нашим спостереженням знаходилося 76 постраждалих з переломами дистального метаепіфіза променевої 
кістки (ПДМЕПК) зі зміщенням; 36 хворих 3 незрощенням кісток гомілки (НКГ) після переломів і 24 хворих з діабетичною остеоартропатіею стоп (ДОАС) різного ступеня вираженості. На етапах лікування уражені кінцівки фіксувалися напівжорсткою системою фіксації Scotchcast / Softcast. Напівжорстка система фіксації дозволяла проводити активну кінезотерапію кінцівок в сумісних суглобах, апаратний пневмомасаж вже з іммобілізаційного періоду, ранню фізіотерапію. Самообслуговування хворих здійснювалося вже у ранні строки. У 36 хворих з незрощеннями кісток гомілки після проведення хірургічного втручання (сегментарной резекції гомілкової кістки і заміщення дистракционного регенератаом за Ілізаровим або зіставлення уламків 3 внесенням в зону незрощення активних речовин у вигляді «пломби) 3 метою профілактики деформацій регенерату після демонтажу апарату або активації процесу зрощення використовувалася фіксаційна система Softcast / Scotchcast. Система також дозволяла здійснювати ранню функцію ходіння, що знижувало ризик розвитку контрактур суглобів, утворення тромбів; покращувало венозний відток крові. Визначення термоасіметріi $\Delta \mathrm{T}$ проводилося 3 метою уточнення обсягу та довго тривалості консервативної терапії. Вимірювання проводилося за допомогою інфрачервоного безконтактного термометра TERMOFOCUS 01500 A3.

Для оцінки отриманих результатів лікування ПДМЕПК використовувалася візуально-аналогова шкала ВАШ (вираженість больового синдрому); з метою уніфікованої оценкі функціі верхньої кінцівки використовувався системний опитувальник DASH (Disabilityofthe Arm, Shoulderand Hand Outcome Measure); опитувальна шкала DN4 для визначення вираженості нейропатичних порушень. Функція нижньої кінцівки у хворих 3 незрощеннями великогомілкової кістки визначалася за шкалами Любошице - Маттіса -Шварцберга та KarlstromOlerud за багатьма параметрами.

Результати та обговорення. Використання системного підходу при лікування (проведення напівжорсткої фіксації Softcast / Scotchcast i об'єктивного визначення строків і об'єму реабілітаційних заходів) дозволило досягти хороших результатів у більшості випадків у хворих iз захворюваннями та переломами променевої кістки у типовому місці, незрощення кісток гомілки після переломів та діабетичними остеоартропатіями стоп.

За даними опитувальних шкал DASH задовільні і гарні результати лікування отримані у хворих з ПДМЕПК в 72,2\% випадках. 
При лікуванні ДОАС з використанням напівжорсткої індивідуальної системи фіксації Softcast / Scotchcast досягалася стабільність, 3'являлася можливість почати функціональне навантаження в ранньому періоді. Не розвивалася м'язова атрофія i, як загальний результат, поліпшувалися результати реабілітації хворих. У 2 хворих перев'язки трофічних виразок здійснювалися через «вікна», спостерігалася тенденція до їх закриття.

У постраждалих 3 незрощеннями великогомілкової кістки результати лікування слід рахувати як гарні. За шкалою Любошице - Маттіса - Шварцберг та та Karlstrom-Olerud у постраждалих з НКГ хороші і відмінні результати були отримані в 65,6\% спостережень.

Висновки.

1. Властивості напівжорсткої фіксації і конструктивні особливості полімерної пов'язки знижували ризик розвитку критичного набряку сосдавленіем тканин, вторинного зміщення відламків; дозволяли функціональне навантаження, кинезотерапию і пневмомассаж в ранньому іммобілізаційному періоді.

2. Визначено ефективність запропонованих заходів - відмінні і добре функціональні результати при знятті системи полімерної полужесткой фіксації від 72,2\% у хворих з ПДМЕПК і 65,6\% у постраждалих з септичними незрощеннями великогомілкової кістки.

\section{Лiтература:}

1. Rushai, A., Bogdanova, L., Klymovytskyy, F., \& Lisunov, S. EARLY COMPLEX REHABILITATION TREATMENT OF PATIENTS WITH FRACTURE OF DISTAL METAEPIPHYSIS OF THE RADIUS. Medical Science of Ukraine (MSU). 2020. №16(2). 23-28. https://doi.org/10.32345/2664-4738.2.2020.4

2. Korzh N.A., Kotulsky I.V. Pathogenesis of post-traumatic pain syndromes of extremities // International medical journal. 2002. 1-2. 134-7. [In Russian] 